\title{
14. MARINE DIATOM BIOSTRATIGRAPHY OF SELECTED SAMPLES FROM THE EQUATORIAL PACIFIC, DSDP LEG 33
}

\author{
Hans-Joachim Schrader, Geologisch-Paläontologisches Institut, Universität Kiel, \\ D-23 Kiel, F.R. Germany
}

Six core-catcher samples were forwarded to the author by E. Martini for marine planktonic diatom biostratigraphy. Two samples are from DSDP Site 316 and four from DSDP Site 315 (Figures 1,2); they were prepared for study according to the standard method (Schrader, 1974). This study was financially supported by the International Program of Ocean Drilling of the Deutsche Forschungsgemeinschaft.

Samples 315-1, CC and 316-1, CC (Nos. 1 and 5) contain a well-diversified diatom assemblage with the following main constituents; stratigraphic indicator species are marked with an asterisk:

Coscinodiscus africanus $\mathrm{F}^{*}$

Coscinodiscus nodulifer $\mathrm{F}$

Coscinodiscus crenulatus $\mathrm{R}$

Coscinodiscus lineatus $\mathrm{F}$

Ethmodiscus rex fragments $\mathrm{F}$

Actinocyclus ellipticus $\mathbf{R}$

Hemidiscus cuneiformis $\mathrm{R}$

Nitzschia marina $\mathrm{R}$

Nitzschia reinholdii $\mathrm{R}^{*}$

Pseudoeunotia doliolus $\mathrm{F}^{*}$

Asteromphalus robustus $\mathrm{F}$

Thalassiosira oestrupii $\mathrm{F}^{*}$

Thalassiosira excentrica $\mathrm{R}$

Roperia tesselata $\mathrm{F}$

Thalassionema nitzschioides A

Thalassiothrix longissima $\mathrm{C}$

Rhizosolenia bergonii $\mathrm{F}^{*}$

Rhizosolenia styliformis $\mathrm{R}$

The occurrence of Pseudoeunotia doliolus and Nitzschia reinholdii places these samples in the Nitzschia reinholdii Partial-range Zone of Burckle, 1972 (Figure 2).

Sample 315A-1, CC (Sample No. 2) did not allow an accurate age assignment because of rather poor preservation. The occurrence of Thalassiosira praeconvexa, Nitzschia reinholdii, and $N$. cylindrica places this sample in the lower two-thirds of the Thalassiosira convexa and upper part of the Nitzschia miocenica Partial-range zones of Burckle, 1972.

Samples 315A-2, CC (No. 3) and 316-2, CC (No. 6) contain well-preserved assemblages with the following constituents:

Thalassiothrix longissima A

Thalassionema nitzschioides A

Asterolampra marylandica A

Actinocyclus ellipticus $\mathrm{R}$

Triceratium cinnamomeum $\mathrm{F}$

Coscinodiscus nodulifer $\mathrm{C}$

Coscinodiscus aeginensis $\mathrm{F}^{*}$

Coscinodiscus lineatus $\mathrm{R}$

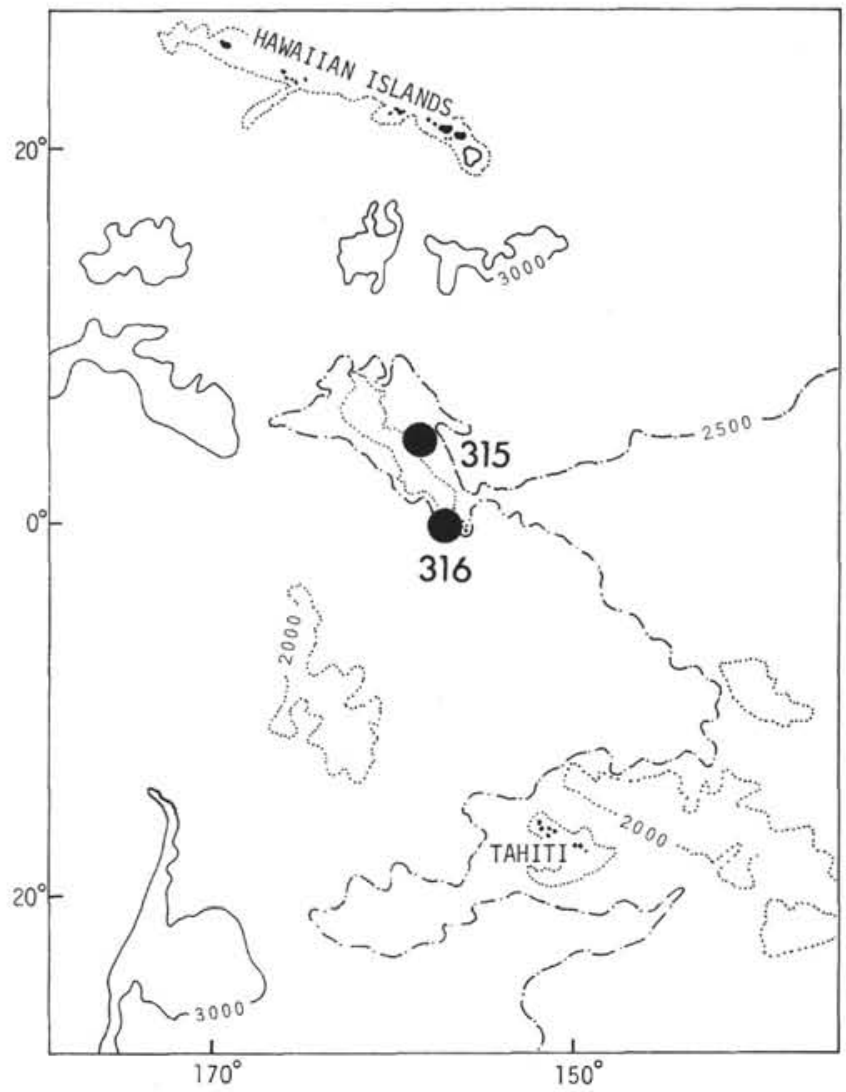

Figure 1. Location of Sites 315, 315A, and 316.

Nitzschia cylindrica $\mathrm{R}^{*}$

Nitzschia porteri Frenguelli $\mathrm{F}^{*}$

Cussia lancettula $\mathrm{R}^{*}$

Sample 6 additional:

Cussia paleacea $\mathrm{R}$

Coscinodiscus yabei $\mathrm{R}^{*}$

Thalassiosira sp. A. Burckle $\mathrm{F}^{*}$

The occurrence of the species listed above places these samples in the Nitzschia porteri Partial-range Zone of Burckle, 1972 (Figure 2).

Sample 315A-3, CC (No. 4) contains a similarly well preserved and diversified assemblage with common Coscinodiscus yabei, C. aeginensis, Nitzschia porteri, and Cussia paleacea; these occurrences place this sample well into the uppermost part of the Coscinodiscus yabei Partial-range Zone of Burckle, 1972 (Figure 2). Correlation of the East Equatorial diatom zonation (Burckle, 1972 ) with the North Pacific diatom zonation (Schrader, 1973 ) and thus to the paleomagnetic stratigraphy (Opdyke, 1972) is shown in Figure 2. 


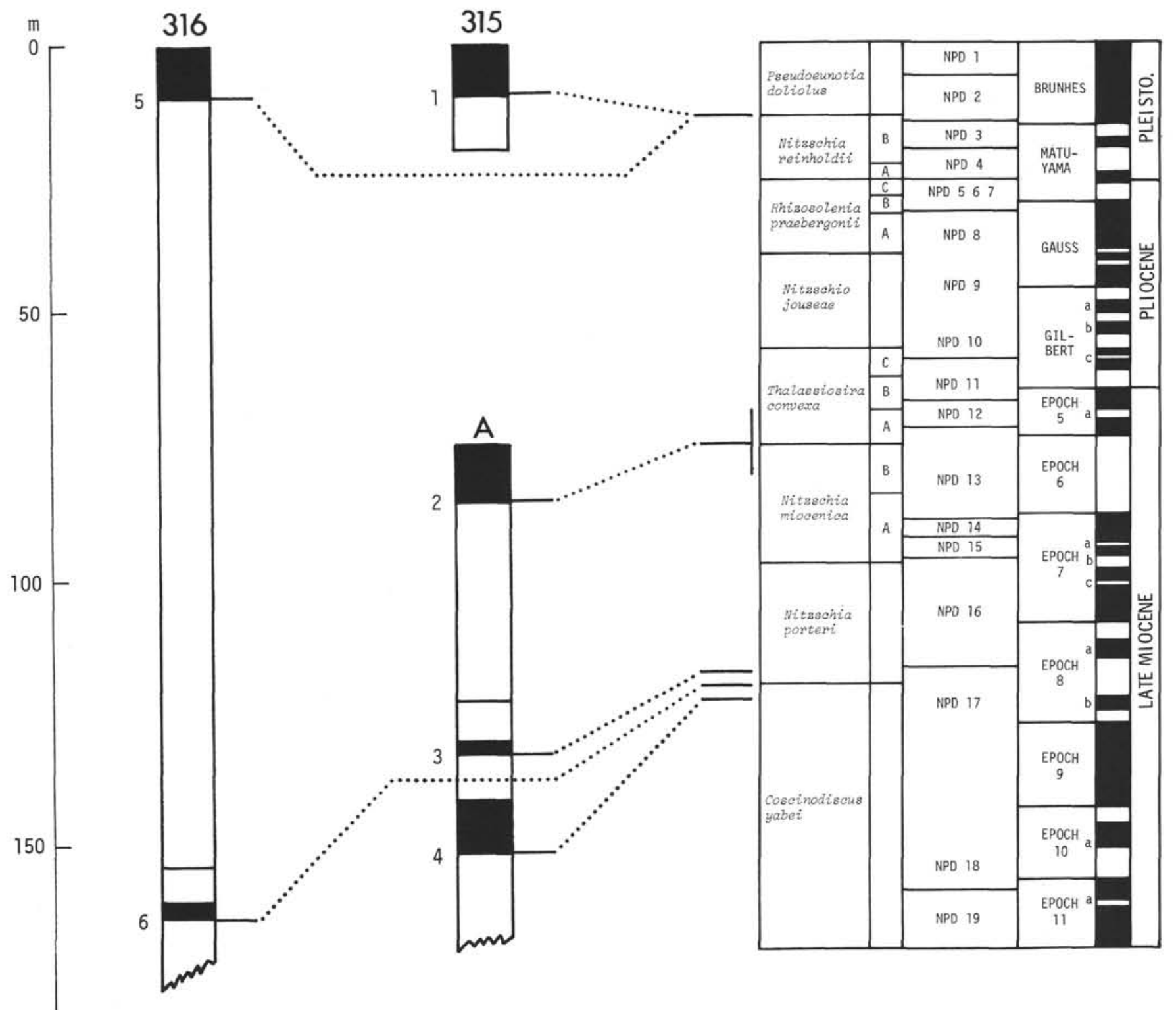

Figure 2. Correlation of Samples 1-6 with the East Equatorial Pacific diatom zonation (Burckle, 1972) with the North Pacific diatom zonation (Schrader, 1973) and the paleomagnetic stratigraphic record (Opdyke, 1972).

\section{REFERENCES}

Burckle, L.H., 1972. Late Cenozoic planktonic diatom zones from the Eastern Equatorial Pacific: Nova Hedw. Beihft., v. 39 , p. 217.

Opdyke, N.D., 1972. Paleomagnetism of deep-sea cores: Rev. Geophys. Space Phys., v. 10, p. 213

Schrader, H.-J., 1973. Cenozoic diatoms from the Northeast Pacific, Leg 18. In Kulm, L.D., von Heune, R., et al., Initial
Reports of the Deep Sea Drilling Project, Volume 18: Washington (U.S. Government Printing Office), p. 673.

1974. Proposal for a standardized method of cleaning diatom-bearing deep-sea and land-exposed marine sediments: Nova Hedw., Beihft., v. 45, p. 403. 